\title{
Influences of Internal Service Quality, Employee Satisfaction, External Service Satisfaction And Customer Satisfaction Toward Customer Loyalty Of Gojek Service Users in Malang
}

\author{
Muhammad Rudijav Andalas \\ Department of Magister Management, STIE Perbanas University Surabaya, Surabaya \\ e-mail: rudijavmohammad@gmail.com
}

\begin{abstract}
This research aims to examine and analyze internal service quality influences toward external service quality and employee satisfaction; to examine and analyze employee satisfaction influences toward external service quality and customer satisfaction; to examine and analyze external service quality toward customer satisfaction; and to examine and analyze customer satisfaction influences toward customer loyalty of Gojek service users in Malang. The research type used is Explanatory Research. The investigation type in this research is determining causal relation. The population consists of samples of 150 employees [driver] and Gojek customers in Malang. The technique of taking samples in this research is using purposive sampling. The analysis technique used in this research is SEM operated through AMOS 18. From the analysis results, it can be concluded that internal service quality has influences toward external service quality and employee satisfaction by the values of CR as respectively 2.794 and 5.436 and also p-value smaller than 0.05 . Employee satisfaction does not have influences toward external service quality by the value of $C R$ as 0.908 and p-value bigger than 0.05 , but employee satisfaction has influences toward customer satisfaction by $C R$ as 2.029 amd p-value smaller than 0.05 . External service quality has influences toward customer satisfaction by $C R$ as 2.739 and p-value smaller than 0.05 . Then, customer satisfaction has influences toward service user loyalty by $C R$ as 4.451 and pvalue smaller than 0.05. Conclusions is Internal Service Quality has influences toward External Service Quality of Gojek service users in Malang, Internal Service Quality has influences toward Employee Satisfaction of Gojek service users in Malang, Employee Satisfaction does not have influences toward External Service Quality of Gojek service users in Malang, Employee Satisfaction has influences toward Customer Satisfaction of Gojek service users in Malang, External Service Quality has influences toward Customer Satisfaction of Gojek service users in Malang, Customer Satisfaction has influences toward Loyalty of Gojek service users in Malang.
\end{abstract}

Keywords- Internal Service Quality, External Service Quality, Employee Satisfaction, Customer Satisfaction.

\section{INTRODUCTION}

$\mathrm{T}$ HE RAPID TECHNOLOGICAL development emerges companies based on technologies, many applications based on technologies offer many kinds of facilities, one of them is online transportation service. Gojek is one of online transportation service servers that has rapid development, it began from one call center that helps commuters for getting motorcycle taxis drivers in 2010. The significant development happened in 2014, i.e. after came Uber and Grab began to come into Indonesia by the car-sharing service. This case attracts investors by idea of taxibike on demands. This case makes Gojek become one of superior start-up and it is the biggest consumer technological company in Indonesia.

By rapid Gojek development and increases of the total Gojek employees and Gojek service users, it is impact from Gojek internal service level toward employees and it implicates on employee performance level so it emerges maximal external service quality and results customer satisfaction. Besides that, Malang City selection as the research location because Malang city is student city so many Gojek drivers are students who work for filling their spare times for adding their incomes. Majority of Gojek customers in Malang city are also students, so it emerges customer satisfaction because there are status similarities between drivers as service givers and customers as service receivers, i.e. they have the same statuses as students. This case enables to make positive bondings between service givers and service receivers because they have the same statuses as students, so they can understand customer needs well. Besides that, when holiday seasons come, so demands upon Gojek services will decrease because the customers with student statuses will return to their original areas, likewise Gojek drivers who also have statuses as students will also return to their original areas and parts of them mutate temporarily as Gojek drivers in their original areas.

By the backgrounds above, so the research has interests for conducting research and knowing how big are influences of Gojek internal service level toward employee satisfaction, Gojek external service level toward customer satisfaction toward Loyalty of Gojek service customers. In which the respondents in this research are Gojek drivers or riders for knowing relation of internal service quality toward employee satisfaction, internal service quality toward external satisfaction, and relation of employee satisfaction toward external satisfaction, and relation of employee satisfaction toward customer satisfaction. Whereas for measuring relation of external service quality toward customer satisfaction and 


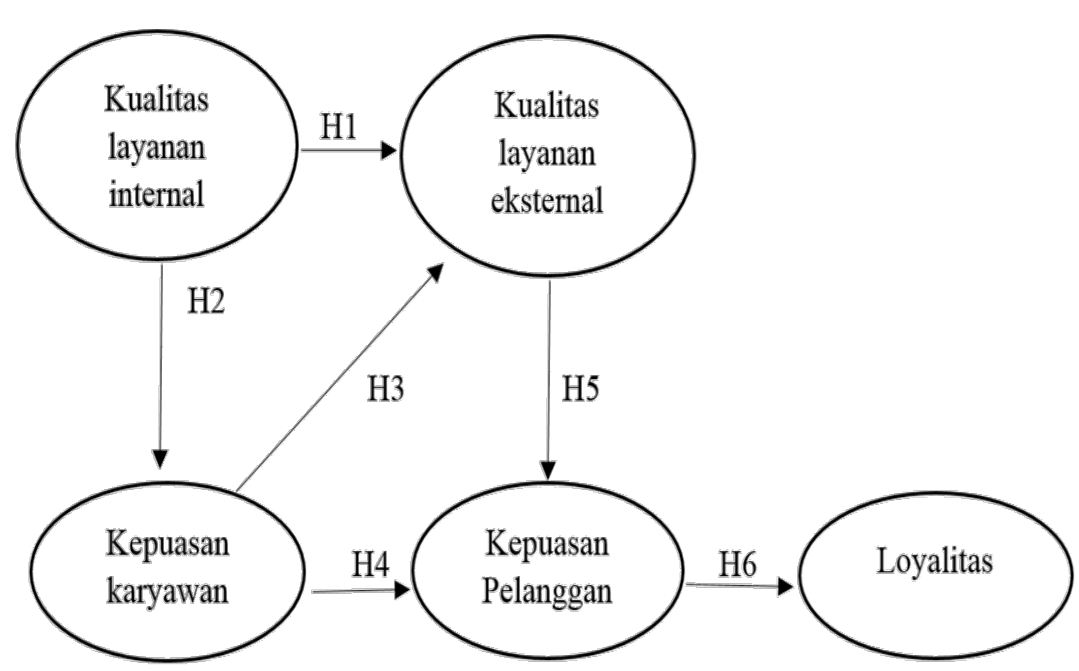

Picture 1. Research Framework

Research Hypothesis

$\mathrm{H}_{1}$ : There are significant influences of internal service quality toward external service quality of Gojek service users in Malang

$\mathrm{H}_{2} \quad$ : There are significant influences of internal service quality toward employee satisfaction of Gojek employees in Malang

$\mathrm{H}_{3} \quad$ : There are significant influences of employee satisfaction of employee toward external service quality of Gojek service users in Malang

$\mathrm{H}_{4} \quad$ : There are significant influences of employee satisfaction toward customer satisfaction of Gojek service users in Malang

$\mathrm{H}_{5} \quad$ : There are significant influences of external service quality toward customer satisfaction of Gojek service users in Malang

$\mathrm{H}_{6} \quad$ : There are significant influences of customer satisfaction toward loyalty of Gojek service users in Malang

Table 1.

Class Interval

\begin{tabular}{ccc}
\hline \hline Interval & Category & Value \\
\hline $1.00 \leq \mathrm{a} \leq 1.80$ & Very disagreed & 1 \\
$1.81 \leq \mathrm{a} \leq 2.60$ & Disagreed & 2 \\
$2.61 \leq \mathrm{a} \leq 3.40$ & Neutral & 3 \\
$3.41 \leq \mathrm{a} \leq 4.20$ & Agreed & 4 \\
$4.21 \leq \mathrm{a} \leq 5.00$ & Very agreed & 5 \\
\hline \hline
\end{tabular}

also relation of customer satisfaction toward customer loyalty, the respondents are Gojek customers.

This research purposes, i.e.: (1) For examining and analyzing influences of internal service quality toward external service quality of Gojek service users in Malang; (2) For examining and analyzing influences of internal service quality toward Gojek employee satisfaction in Malang; (3) For examining and analyzing influences of ermployee satisfaction toward external service quality of Gojek service users in Malang; (4) For examining and analyzing influences of employee satisfaction toward customer satisfaction of Gojek service users in Malang; (5) For examining and analyzing influences of external service quality toward customer satisfaction of Gojek service users in Malang; (6) For examining and analyzing influences of customer satisfaction toward customer loyalty of Gojek service users in Malang.

\section{METHOD}

A. Relation of Internal Service Quality and External Service Quality

It is important thing because service toward internal customer is determinant of company performance and service quality entirely. Internal service quality is starting point and link in company growth and sustainability. If service toward internal customer is hampered, so service performance and process will be also hampered. So, everyone in the company must relate and support each other, because although the person does not interact directly to external customer, but he/she interacts to the person who interacts directly to external customer. From the previous research results, there are significant and positive relations between internal service quality and external service quality (Rachmat, B and Indrawati, T, (2012); Susanti, E et al (2015); Bouranta, N and Chirtis L (2009))

B. Relation of Internal Service Quality and Employee Satisfaction

Service quality is comparison between consumer hopes about one service and service processes they feel. Employee herself/himself is company internal consumer in which the condition of one employee feels satisfied toward the services they feel and it becomes barometer in applying service standard given. When internal service quality of company is good, so the employees will be satisfied and it impacts on good employee performances, too, and otherwise, when the internal service quality is not good, so the employee performance level is also not good. Care concept of customer will be considerably understood if everyone in the company realizes that they have customers and the performances determine performances of other people in the company. From the previous research results, there are significant and 
Table 2.

Research Variable, Research Indicator

\begin{tabular}{|c|c|c|}
\hline $\begin{array}{l}\text { Variable and } \\
\text { Definition } \\
\end{array}$ & Indicator & Source \\
\hline $\begin{array}{l}\text { Internal Service } \\
\text { Quality }\end{array}$ & $\begin{array}{l}\text { Responsiveness. } \\
\text { - Service accuracy among employees } \\
\text { Empathy. } \\
\text { - Individual service in the name of internal service server } \\
\text { - Politeness in the name of internal service server } \\
\text { Safety. Safe feeling felt by employees in company activities. } \\
\text { - Confidence embedded by internal service server } \\
\text { - Internal server performance that mostly influences confidence } \\
\text { Professionalism. } \\
\text { - Mastery upon job } \\
\text { Tangibles. } \\
\text { - Workplace cleanliness } \\
\text { Reliability. } \\
\text { - Accuracy level upon each job } \\
\text { - Punctuality } \\
\text { Care } \quad \text { Service reliability given by internal server to their customers. }\end{array}$ & $\begin{array}{c}\text { Bouranta, N and Chirtis } \\
\text { L (2009) }\end{array}$ \\
\hline Employee Satisfaction & 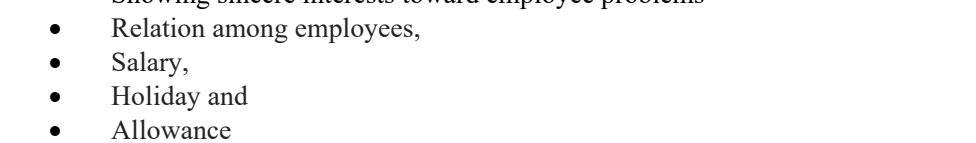 & Yunus, N (2012) \\
\hline $\begin{array}{l}\text { External Service } \\
\quad \text { Quality }\end{array}$ & $\begin{aligned} \text { 1. Tangible } & \\
- & \text { Proper tools } \\
- & \text { Modern tools } \\
: & \text { The facilities offered are interesting } \\
& \text { Vehicle cleanliness } \\
& \text { Gojek driver appearances are good-looking }\end{aligned}$ & $\begin{array}{c}\text { Rachmat, B and } \\
\text { Indrawati, T, (2012) }\end{array}$ \\
\hline & 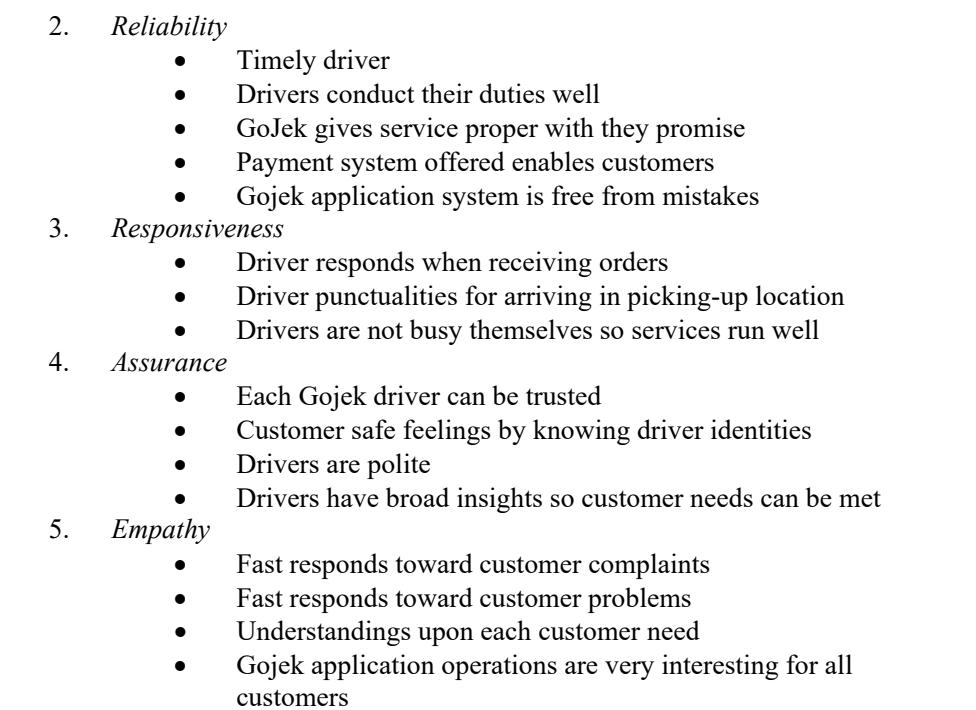 & \\
\hline Customer Satisfaction & $\begin{array}{l}\text { - } \quad \text { Good product and service quality } \\
\text { - } \quad \text { Eood service quality or proper with hopes } \\
\text { - The prices relatively cheaper but they have higher values } \\
\text { - Cost, customers do not need to spend additional costs or they do not need to } \\
\text { waste time for getting products or services }\end{array}$ & Lupyoadi (2001) \\
\hline Customer Loyalty & $\begin{array}{l}\text { - } \quad \text { Conducting repurchase regularly } \\
\text { - } \quad \text { Conducting purchases between product and service lines } \\
\text { - } \quad \text { Showencing to other people } \\
\text { - }\end{array}$ & Griffin (2005) \\
\hline
\end{tabular}

positive relations between internal service quality and employee performance satisfaction (Rachmat, B and Indrawati, T, (2012); Nazeer, S et al (2014)).
C. Relation of Employee Satisfaction and External Service Quality

Strong cooperation among employees, conducive work situation, efficient structure and system, qualified work and 
Table 3.

Hypothesis Examination

\begin{tabular}{cccccc}
\hline \multicolumn{7}{c}{ Hypothesis Examination } & Note \\
\hline KLE<---KLI & Estimate & S.E. & C.R. & P & Significant \\
KK<---KLI & 0.295 & 0.079 & 2.794 & 0.005 & Significant \\
KLE<---KK & 0.513 & 0.110 & 5.436 & 0.000 & Insignificant \\
KP<---KK & 0.097 & 0.069 & 0.908 & 0.364 & Significant \\
KP<---KLE & 0.199 & 0.082 & 2.029 & 0.042 & Significant \\
LP<---KP & 0.260 & 0.123 & 2.739 & 0.006 & Significant \\
\hline \hline
\end{tabular}

Table 4.

Criteria Evaluation of Goodness of Fit Indices

\begin{tabular}{ccccc}
\hline \hline No. & KriteriaGoodness of Fit & Result & Cut-off Value & Model Evaluation \\
\hline 1. & Chi-square $(\chi 2)$ & 1,077 & It is hoped to be small & Smaller [Significant] \\
2. & Probability $(\rho)$ & 0,092 & $\geq 0.05$ & Fit \\
3. & CMIN/DF $(\chi 2 / d f)$ & 1,059 & $<2.00$ & Fit \\
4. & GFI & 0,783 & $0,80-0,90$ & Marginal \\
5. & AGFI & 0,759 & $0,80-0,90$ & Marginal \\
6. & RMSEA & 0,020 & $\leq 0,08$ & Fit \\
7. & CFI & 0,984 & $\geq 0.90$ & Fit \\
8. & TLI (NNFI) & 0,983 & $\geq 0.95$ & Fit \\
\hline \hline
\end{tabular}

timely completeness and also company care toward employee will influence service quality that will be given to external customer. But in previous research, there is no significant relation between employee satisfaction and service quality.

D. Relation of Employee Satisfaction and Customer Satisfaction

Employee as company internal customer has hopes about satisfaction in working and this case can be reflected such as relation of superior and subordinate, relation among employees and relation of employee and customer. The hope is when employee is satisfied so customer will be also satisfied upon the employee performance. From the previous research, from the relation between employee satisfaction and customer satisfaction, there is no significant relation. (Yunus, NKY (2012))

\section{E. Relation of External Service Quality and Customer Satisfaction}

Service quality is satisfaction benchmark from one product or service and it depends on the product or service abilities for satisfying customer needs and hopes. So, service quality is meeting customer needs and wishes and also determination of delivering them for balancing customer hopes. From the previous research results, there are positive relations between service quality and customer satisfaction. (Rachmat, B and Indrawati, T, (2012); Aburoub, A et al (2011)

F. Relation of Customer Satisfaction and Customer Loyalty

Customer satisfaction is customer satisfaction level after conducting comparison between what he/she receives and his/her hopes. When someone is satisfied upon product or service value, most likely he/she will become customer for a long time. One loyal customer has specific prejudice about what will be purchased and from whom. Loyal customer will conduct same brand purchases repetitively. From the previous results, there are significant relations between customer satisfaction and customer loyalty. (Rachmat, B and Indrawati, T, (2012); Mosabah, R et al (2010)).

\section{RESEARCH METHODOLOGY}

Research variable is characteristic that will be observed from some research of Supriadi (2013). And based on research hypothesis, the variables in this research can be identified as follows:

1. Exogenous Variable: Internal Service Quality

2. Intervening exogenous variable: External Service Quality, Employee Satisfaction, Customer Satisfaction

3. Endogenous Variable: Customer Loyalty

In this research, variable measurement uses likert scale, likert scale is used for measuring attitude, opinion, and perception of someone or a group of people about social phenomena (Sugiyono, 2015). In the research of social phenomena, it has been determined specifically by the researcher, then it is called by research variable. The variables that will be measured are described to be variable indicators. The technique used uses the answers achieved by using research instruments given scores. The Likert scale shows interpretation: very agreed is given score 5, agreed is given score 4, neutral/hesitated is given score 3, disagreed is given score 2 , and very disagreed is given score 1 .

Then, for categorizing respondent answer means, it is made interval scales calculated from the highest scores reduced by the lowest scores then divided by five, achieved intervals for categories as 0.80 ,

Class Interval $=$ The Highest Value - The Lowest Value/The Total Classes

Class Interval $=5-1 / 5=0,8$

From the class intervals, so it can be known the value limitations of each class and after that, the values of each one will be formulated in Table 1.

The technique of taking samples in this research is using purposive sampling, i.e. sample determination for determining clear purposes by selecting respondents. In SEM itself, the samples for the research are determined minimally as 100 respondents, so in this research, the researcher tries to draw samples as 150 Gojek employees and 150 Gojek customers. So, the criteria are Gojek employees who have worked for minimally 1 year and for customers, i.e. customers with ages of minimally 17 years and they have used Gojek services for minimally 1 years and also in the latest 3 months, they have used Gojek services.

The research location is conducted in Gojek office Malang, and customers of Gojek service users in Malang area. This 
research uses questionnaires as instruments in collecting data from respondents, because the method of collecting data in this research is survey. The questionnaires consist of the total written question items, respondents are asked for giving responds proper with their.

\section{FINDINGS}

Structural similarity is function or model of causality relation among the variables researched and hypothesized. This research shows that there is one endogenous variable, 3 intervening variables and one exogenous variable. From the SEM analysis results by AMOS, it is gotten two research similarities, they are:

$\mathrm{KK}=513 \mathrm{KLI}+\mathrm{e}$

$\mathrm{KLE}=0.295 \mathrm{KLI}+0.097 \mathrm{KK}+\mathrm{e}$

$\mathrm{KP}=0,199 \mathrm{KK}+0,260 \mathrm{KLE}+\mathrm{e}$

$\mathrm{Y}=0,443 \mathrm{KP}+\mathrm{e}$

Based on the structural similarity, it can be explained as follows:

1. Internal Service Quality influences positively toward Employee Satisfaction by influence coefficient as 0.513 . The direct influence value scale describes that the happening internal service quality improvement will also improve employee satisfaction as 0.513 for each increase of 1 deviation standard. Likewise when it happens decreases toward internal service quality, so Customer Satisfaction, health employees, employee satisfaction will experience decrease as 0.513 .

2. Internal Service Quality influences positively toward External Service Quality by influence coefficient as 0.295 . This case means if internal service quality increases, so external service quality will also increase. In structural similarity, it is also gotten the results of Employee Satisfaction influences positively toward External Service Quality by influence coefficient as 0.097. This case means if employee satisfaction increases, so it will also increase external service quality.

3. Employee Satisfaction influences positively toward Customer Satisfaction by influence coefficient as 0.199 . This case means if it happens increases in employee satisfaction, so it will also increase customer satisfaction. In structural similarity, it is also gotten the results that External Service Quality influences positively toward Customer Satisfaction by influence coefficient as 0.260 . This case means if it happens increases in external service quality, it will also increase customer satisfaction.

4. Customer Satisfaction influences positively toward Customer Loyalty by influence coefficient as 0.443 . The influence value scale describes that the happening customer satisfaction increase will also increase customer loyalty as 0.443 for each increase of 1 deviation standard.

In hypothesis examination, it is conducted examination toward structural similarity coefficients by specifying certain significance level. In this research, it is used $\mathrm{P}=0.05$, so critical ratio from structural similarity must be $\geq 1,96$. The results of Hypothesis Examination are as follows Table 3.

From Table 3 above, so the results of hypothesis examination results can be explained as follows:
1. CR value between Internal Service Quality and External Service Quality of Gojek service users in Malang is as 2.794 by probability as 0.005 or $\mathrm{p}<0,05$. This case shows that variable of Internal Service Quality influences significantly toward External Service Quality of Gojek service users in Malang.

2. CR value between Internal Service Quality and Customer Satisfaction of Gojek service users in Malang is as 5.536 by probability as 0.000 or $\mathrm{p}<0,05$. This case shows that variable of Internal Service Quality influences significantly toward variable of Employee Satisfaction of Gojek service users in Malang.

3. CR value between Employee Satisfaction and External Service Quality of Gojek service users in Malang is as 0.908 by probability as 0.364 or $p>0,05$. This case shows that Employee Satisfaction dose not influence significantly toward External Service Quality of Gojek service users in Malang.

4. CR value between Employee Satisfaction and Customer Satisfaction of Gojek service users in Malang is as 2.029 by probability as 0.042 or $\mathrm{p}<0,05$. This case shows that variable of Employee Satisfaction influences significantly toward variable of Customer Satisfaction of Gojek service users in Malang.

5. CR value between External Service Quality and Customer Satisfaction of Gojek service users is as 2.739 by probability as 0.006 or $\mathrm{p}<0,05$. This case shows that variable of External Service Quality influences significantly toward variable of Customer Satisfaction of Gojek service users in Malang.

6. CR value between Customer Satisfaction and Customer Loyalty of Gojek service users in Malang is as 4.451 by probability as 0.000 or $p<0,05$. This case shows that variable of Customer Satisfaction influences significantly toward variable of Gojek service users in Malang.

Based on Table 4, all values of goodness of fit are good, proper with cut of value. Therefore, it can be said that empirical data used have been proper with conceptual framework.

\section{A. Influences of Internal Service Quality toward External} Service Quality

Based on the research results, so the finding in this research is Internal Service Quality has influences toward External Service Quality. This case can be seen from CR value as 2.794 by the value of $p$-value as 0.005 or less than 0.05 , it can be meant that external service quality can be formed through good internal service quality. Seeing the results, so the first hypothesis in this research that sounds "There are significant influences of internal service quality toward external service quality of Gojek service users in Malang is accepted. Influences of internal service quality toward external service quality are positive in which the case is showed through estimate value as 0.295 , it means if it happens increases in internal service quality so external service quality will also increase. There are positive influences of internal service quality toward external service quality shows that the better the internal quality given so it will also give impacts on external service quality increases. The finding results in this research support the research findings conducted by 
RachmatandIndrawati (2012) who proved that there are significant influences from internal service quality toward external service quality. The results in this research are also parallel withSusantics (2015) who proved that internal service quality has significant and direct positive influences in external service quality. Likewise BourantaandChristis (2009) who proved that internal service quality in which safety, reliability and internet give positive influences toward external service quality dimension, i.e. organizational image. B. Influences of Internal Service Quality toward Employee Satisfaction

Based on the research results, so the finding in this research is Internal Service Quality has influences toward Employee Satisfaction. This case can be seen from CR value as 5.436 by $p$ value as 0.000 or less than 0.05 , it means that satisfaction felt by employees can be formed by good internal service quality. Seeing the results, so the second hypothesis in this research that sounds "There are significant influences of internal service quality toward Gojek employee satisfaction in Malang is accepted. The analysis results are found that internal service quality has significant influences toward employee satisfaction positively. This case is proved by estimate value as 0.513 , so it can be meant that the higher the internal service quality given, so it will increase and increase employee satisfaction. By seeing these results, so it can be meant that if Gojek parties wants to increase working employee satisfaction, so it is very important for Gojek parties for caring to what extent internal service quality given. The findings in this research support research findings conducted by Rachmat and Indrawati (2012) who proved that there are significant and positive influences from internal service quality toward employee satisfaction. The research results of Nazeer, Zahid, andAzeem (2014) are also proved that internal service quality influences significantly toward performance satisfaction.

\section{Influences of Employee Satisfaction toward External Service Quality}

Based on the research results, so the finding in this research is Employee Satisfaction does not have influences toward External Service Quality. This case can be seen from CR value as 0.908 by the value of $p$-value as 0.364 or more than 0.05 , it means that high external service quality cannot surely be increased by satisfied feelings by customers. Seeing the results, so the third hypothesis in this research that sounds "There are significant influences of employee satisfaction toward external service quality of Gojek service users in Malang is unaccepted. The hypothesis examinational results are proved that there is no significant influence of employee satisfaction toward external service quality but it has influences positively known from estimate value as 0.069 . The positive influences indicate there are influences in the same direction so it can be meant that the higher the satisfaction felt by employees, so it will increase and increase external service quality given but they have small influences and they are insignificant. Therefore, if Gojek parties want to increase external service quality given, so it is very important for Gojek parties for caring satisfaction level by employees. The results in this research support the research findings conducted by Widodo (2009) in which in his research was found that there is no correlation between work satisfaction and external service quality. The same case was also found by RachmatandIndrawati (2012) who also found that there is no significant influence from employee satisfaction toward external service quality.

\section{Influences of Employee Satisfaction toward Customer} Satisfaction

Based on the research results, so the finding in this research is Employee Satisfaction has influences toward Customer Satisfaction. This case can be seen from CR value as 2.029 by $p$ value as 0.042 or less than 0.05 , it can be meant that satisfaction felt by customer can be formed through high employee satisfaction. Seeing the results, so the fourth hypothesis in this research that sounds "There are significant influences of employee satisfaction toward customer satisfaction of Gojek service users in Malang is accepted. The research findings are achieved that employee satisfaction has significant influences toward customer satisfaction by positive influence directions. Positive influences that happen indicates that the higher the satisfied feelings felt by employees, so it will drive increases in customer satisfaction. By seeing this results, so it can be said that if Gojek parties wants to increase customer satisfaction, so it is very important for Gojek parties for caring satisfaction felt by Yunus (2012) in which in his research was found that there is no relation between internal satisfaction and external satisfaction

\section{E. Influences of External Service Quality toward Customer Satisfaction}

Based on the research results, so the finding in this research is External Service Quality has influences toward Customer Satisfaction. This case can be seen from CR value as 2.739 by $p$ value as 0.006 or less than 0.05 , it means that satisfied feelings felt by customer can be increased by good external service quality. Seeing the results, so the fifth hypothesis in this research that sounds "There are significant influences of external service quality toward customer satisfaction of Gojek service in Malang is accepted. The hypothesis examinational results in this research are proved that external service quality has significant influences positively toward customer satisfaction. These positive influences can be meant that there are influences in the same direction so it can be meant that the better the external service quality given, so it will trigger and trigger increases in customer satisfaction. Therefore, if Gojek parties want to increase satisfied feelings felt by customers, so it is very important for Gojek parties for caring to what extent external service quality given. The analysis results in this research support the research findings conducted by Rachmat and Indrawati (2012) who proved that there are significant and positive influences from external service quality in customer satisfaction.

\section{F. Influences of Customer Satisfaction toward Loyalty of Service Users}

Based on the research results, so the finding in this research is Customer Satisfaction has influences toward Loyalty of Service Users. This case can be seen from CR value as 4.451 by $p$ value as 0.000 or less than 0.05 , it means that loyalty of one customer toward uses of some service can be increased through satisfaction felt in the minds of customers. Seeing the 
results, so the sixth hypothesis in this research that sounds "There are significant influences of customer satisfaction toward loyalty of Gojek service users in Malang is accepted. Based on the analysis results conducted, it is achieved the results that customer satisfaction has significant influences toward customer loyalty by positive influence direction or in the same direction. The influences in the same direction can be meant that the higher the customer satisfaction, so it will trigger and trigger increases in loyalty of users. Therefore, if Gojek parties want to get high customer loyalty, so it is very important for Gojek driver for caring to what extent satisfied feeling level felt by customers. The analysis results in this research support the research findings conducted by Mosahab, Mahamad, and Ramayah (2010) who found that customer satisfaction can increase customer loyalty significantly.

\section{CONCLUSIONS AND RECOMMENDATIONS}

Based on the discussions conducted, so the conclusions that can be taken are as follows: Internal Service Quality has influences toward External Service Quality of Gojek service users in Malang, Internal Service Quality has influences toward Employee Satisfaction of Gojek service users in Malang, Employee Satisfaction does not have influences toward External Service Quality of Gojek service users in Malang , Employee Satisfaction has influences toward Customer Satisfaction of Gojek service users in Malang, External Service Quality has influences toward Customer Satisfaction of Gojek service users in Malang, Customer Satisfaction has influences toward Loyalty of Gojek service users in Malang. Based on the analysis conducted, so it can be given suggestions as follows : It is hoped so that Gojek parties can continue improving internal service quality through managemental politeness improvement toward the employees and also give better individual services so that it will give impacts on improving and improving satisfied feelings in the employee minds. It is hoped so that Gojek employee parties can considerably care customer satisfaction level through external service quality improvement given to customers through improving vehicle cleanliness, punctuality in picking up, and also politeness in serving.

\section{REFERENCES}

[1]. Aburoub, A., Hersh, A. and Aladwan, K. (2011), "Relationship between internal marketing andservice quality with customers' satisfaction", International Journal of Marketing Studies,Vol. 3 No. 2, pp. 107-118.

[2]. Bouranta, N., Chitiris, L., Paravantis, J. (2009), "The relationship between internal and external service quality". International Journal of Contemporary Hospitality Management, 21(3), pp. 275 - 293.

[3]. Griffin, Jill. (2005). Customer Loyalty: Menumbuhkan\&MempertahankanKesetiaanPelanggan. Jakarta : Erlangga.

[4]. Hasan. A. (2008). Marketing. Yogyakarta. Media Pressindo.

[5]. Indrawati, T., dan B. Rachmat. (2012). "Isees Model: Model Of Hospital Service Based On Internal And External Service Quality". Journal of Economics, Business, and Accountancy Ventura 15, (3), pages 457 470.

[6]. Lupiyoadi, R. (2001). ManajemenPemasaranJasa, TeoridanPraktek. EdisiPertama. Jakarta: SalembaEmpat

[7]. Minto. W. (2011). PanduandanAplikasi SEM. Jakarta: PT Indeks.

[8]. Mosabah, R. (2010). "Service Quality, Customer Satisfaction and Loyalty: A Test of Mediation”. International Business Research 3, (4).
[9]. Nazeer, S., M. Mohsin Z., and M. F. Azeem. (2014). "Internal service quality and job performance does job satisfaction mediate", Journal of Human Resources Management and Labor Studies, 2 (1), page 41-65

[10]. Robbin SP, dan Judge, Timothy A., (2008). PerilakuOrganisasiBuku 2. Jakarta,: Salemba.

[11]. Sugiyono (2015). MetodePenelitianKombinasi (Mix Methods). Bandung: Alfabeta.

[12]. Supriyadi, E. (2013). Statistical Data Analysis SPSS+Amos, Penerbit : In Media, Jakarta.

[13]. Susana, J., (2012). Developing the internal service quality in organisation Y. Business Management. Laurea University of Applied Sciences.

[14]. Susanti, E., Ernie Trisnawati, S., and H. Sutisna. (2015). "The Impact of Internal and External Service Quality (A Case Study among Lecturers and Students)". Mediterranean Journal of Social Sciences MCSER Publishing, Rome-Italy. 6 (5) : 77-83.

[15]. Tjiptono, F. (2014). StrategiPemasaran. Edisi 3, Yogyakarta : Andi.

[16]. Widodo, S. (2009). "Tingkat kualitaslayanan internal, kepuasankerjakaryawan, kualitaslayananeksternaldantingkatkepuasanmahasiswa". JurnalBisnisdanEkonomi, 1 (1), 35-55.

[17]. Yunus, NKY. (2012). "The Relationship between Internal Satisfaction and External Satisfaction amongst Hotel Customers in Malaysia," MPRA Paper 42167, University Library of Munich, Germany. 